\title{
Cholesterol Esterase produced by Streptomyces lavendulae. II. ${ }^{1)}$ Purification and Properties as a Lipolytic Enzyme
}

\author{
Toshio Kamei, Hajime Suzuki, Kazuko Asano, Meiki Matsuzakr, ${ }^{2 a)}$ \\ and SHOSHIRO NAKAMURA ${ }^{2 b}$ \\ Institute of Chemical Pharmacology, Banyu Pharmacentical Co., Ltd. ${ }^{2 a)}$ and Institute of \\ Pharmaceutical Sciences, Hiroshima University, School of Medicine ${ }^{2 b)}$
}

(Received February 15, 1979)

\begin{abstract}
Cholesterol esterase was purified about 85 times from the broth filtrate of Streptomyces lavendulae by procedures involving precipitation with ammonium sulfate, reprecipitation with acetone, affinity chromatography on palmitoyl cellulose, and ion exchange chromatography on DEAE-cellulose. The purified enzyme showed a single band on polyacrylamide disc gel electrophoresis and SDS-polyacrylamide gel electrophoresis, and the specific activity of the enzyme was $36.3 \mathrm{U} / \mathrm{mg}$. The molecular weight of the enzyme was 12000 as determined by SDS-polyacrylamide gel electrophoresis. The enzyme showed different properties from other cholesterol esterases as regards its affinity for cholesterol.
\end{abstract}

Keywords-cholesterol esterase; Streptomyces lavendulae; lipolytic enzyme; affinity chromatography; lipase

We have reported the purification of cholesterol esterase (EC 3.1.1.13) from Streptomyces lavendulae by precipitation with ammonium sulfate, reprecipitation with acetone, gel filtration on Sepharose CL-4B and rechromatography on Sepharose CL-4B after treatment with Triton $\mathrm{X}-100 .{ }^{1)} \quad$ However, the purified enzyme gave one main band and three minor bands on SDSpolyacrylamide gel electrophoresis. In the present paper we report a new method for the purification of the enzyme, based on its affinity for palmitoyl cellulose, together with its properties as a lipolytic enzyme.

\section{Materials and Methods}

Chole $\vec{w}$ erol oxidase was prepared from the culture filtrate of Streptomyces violascens as described previously. ${ }^{3)}$ Other enzymes were obtained as follows; lipase from porcine pancreas, peroxidase from horseradish (Sigma Chemical Co.), lipase from Geotrichum candidum (Seikagaku Kogyo Co., Ltd.), cholesterol esterase from microorganisms (Boehringer Mannheim $\mathrm{GmbH}$ ), cholesterol esterase from bovine pancreas (Miles Laboratories Ltd.). All other reagents were purchased from commercial sources and were of analytical grade.

The enzyme activity of cholesterol esterase was measured as described previously. ${ }^{1)}$ The activity of lipase was measured as described by Sugiura et al.4) Palmitoyl cellulose was prepared by the method of Horiuti et al.5) Protein concentrations of enzyme preparations were measured by the method of Lowry et al. ${ }^{6)}$ Protein concentrations in the eluates from palmitoyl cellulose column were measured by the fluorometric method. ${ }^{7}$ Sugar concentration was measured by the method of Dubos et al. ${ }^{8)}$ Polyacrylamide disc

1) Part I: T. Kamei, H. Suzuki, M. Matsuzaki, T. Otani, H. Kondo, and S. Nakamura, Chem. Pharm. Bull. (Tokyo), 25, 3190 (1977).

2) Location: a) 2-9-3, Shimomeguro Meguro-ku Tokyo, 153, Japan; b) 1-2-3 Kasumi Hiroshima, 734, Japan.

3) T. Kamei, Y. Takiguchi, H. Suzuki, M. Matsuzaki, and S. Nakamura, Chem. Pharm. Bull. (Tokyo), 26, 2799 (1978).

4) M. Sugiura, M. Isobe, T. Oikawa, and H. Oono, Chem. Pharm. Bull. (Tokyo), 24, 1202 (1976).

5) Y. Horiuti and S. Imamura, J. Biochem. (Tokyo), 81, 1639 (1977).

6) O.H. Lowry, N.J. Rowebrough, A.L. Farr, and R.J. Randall, J. Biol. Chem., 193, 265 (1951).

7) C. Schwabe, Anal. Biochem., 53, 484 (1973).

8) M. Dubos, K.A. Gilles, J.K. Hamilton, P.A. Rebers, and F. Smith, Anal. Chem., 28, 350 (1956). 
gel electrophoresis was performed by the method of Davis. ${ }^{9)}$ SDS-polyacrylamide gel electrophoresis was also performed by the method of Weber et al. ${ }^{10}$ )

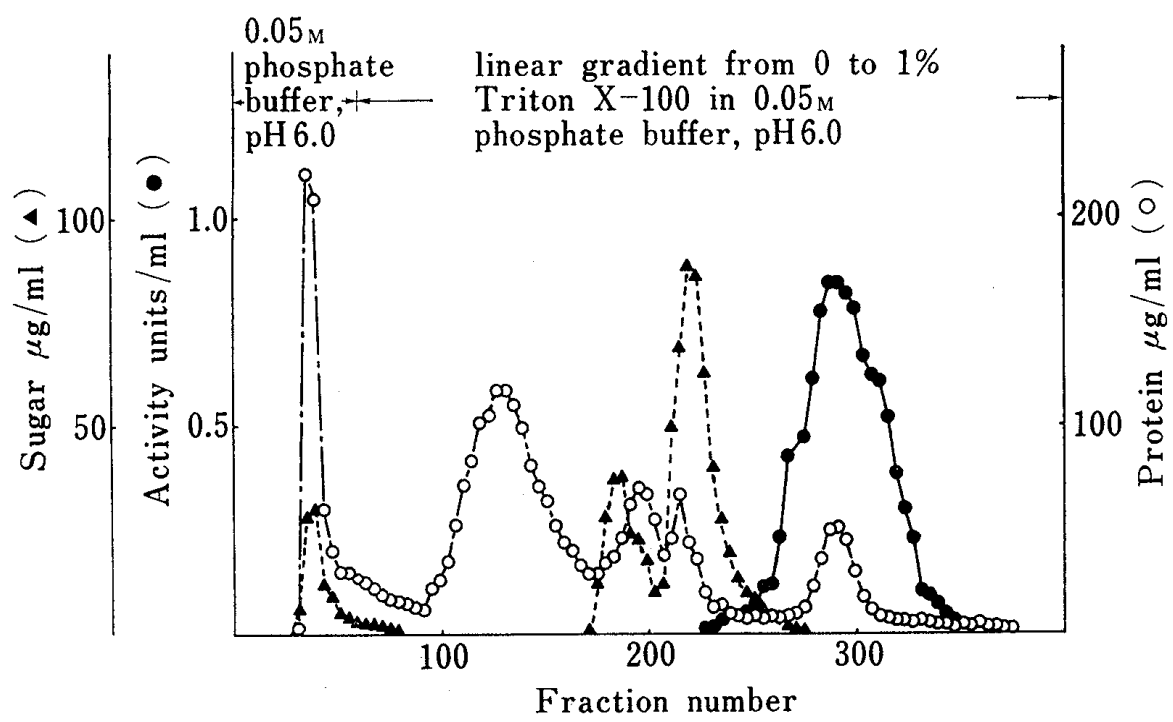

Fig. 1. Chromatography of Cholesterol Esterase on a Palmitoyl Cellulose Column

The acetone-precipitated and dialyzed fraction (1026 Units, $230 \mathrm{mg}$ as protein) was subiected to affinity chromatography on palmitoyl cellulose $(5.2 \times 40 \mathrm{~cm})$. The column was washed with $0.05 \mathrm{M}$ phosphate buffer ( $\mathrm{pH} 6.0$ ) and eluted with a linear concentration gradient from 0 to $1 \%$ Triton $\mathrm{X}-100$ in the same buffer. The flow rate was approximately $250 \mathrm{ml} / \mathrm{hr}$ and $20 \mathrm{ml}$ fractions were collected.

\section{Results and Discussion}

Cholesterol esterase hydrolyzes fatty acid esters of cholesterol. We therefore studied water-precipitable cholesterol and palmitoyl cellulose as affinity adsorbents for cholesterol esterase. The enzyme recovered from the broth filtrate by ammonium sulfate and acetone precipitation could be adsorbed to the extent of about 2 units on $1 \mathrm{ml}$ of palmitoyl cellulose, but could not be adsorbed on water-precipitable cholesterol. The enzyme adsorbed on palmitoyl cellulose could be eluted by detergents such as Triton $\mathrm{X}-100$. Thus, we used palmitoyl cellulose as the enzyme adsorbent.

The cultivation of Streptomyces lavendulae $\mathrm{H}$ 646-SY2, preparation of the broth filtrate, ammonium sulfate fractionation and acetone fractionation were performed as described previously.1) The acetone precipitate was dissolved in $0.05 \mathrm{M}$ phosphate buffer

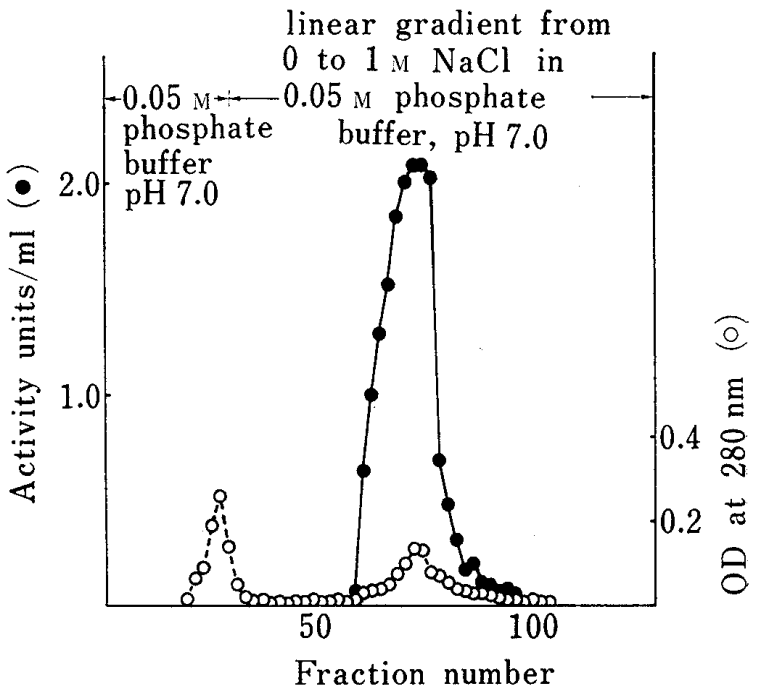

Fig. 2. Chromatography of Cholesterol Esterase on a DEAE-Cellulose Column

Atter chromatography on palmitoyl cellulose, the enzyme preparation (480 Units, $19 \mathrm{mg}$ as protein) was chromatographed on DEAE-cellulose $(3.5 \times 35 \mathrm{~cm})$. The column was washed with $0.05 \mathrm{M}$ phosphate buffer $(\mathrm{pH}$ i.0) and eluted with a linear concentration gradient from 0 to $1 \mathrm{M}$ Narl in the same buffer. The flow rate was approximately $60 \mathrm{ml} / \mathrm{hr}$ and $10 \mathrm{ml}$ fractions were collected.

9) B.J. Davis, Ann. New York Acad. Sci., 121 art., 2, 404 (1964).

10) K. Weber and M. Osborn, J. Biol. Chem., 244, 4406 (1969). 
(pH 6.0) and subjected to affinity chromatography on palmitoyl cellulose. The charged column was washed with a sufficient volume of $0.05 \mathrm{~m}$ phosphate buffer $(\mathrm{pH} 6.0)$ and eluted with a linear concentration gradient from 0 to $1 \%$ Triton X-100 in the same buffer (Fig. 1). Fractions which showed enzyme activity and which did not contain sugar were combined, mixed with 3 volumes of cold acetone, and centrifuged. The precipitate was dissolved in $0.05 \mathrm{~m}$ phosphate buffer ( $\mathrm{pH} 7.0)$ and dialyzed against the same buffer. The dialyzed enzyme was then subjected to chromatography on a DEAE-cellulose column equilibrated with $0.05 \mathrm{~m}$ phosphate buffer $(\mathrm{pH} 7.0)$. The column was washed with $0.05 \mathrm{~m}$ phosphate buffer $(\mathrm{pH} 7.0)$ and eluted with a linear concentration gradient from 0 to $1 \mathrm{~m} \mathrm{NaCl}$ in the same buffer (Fig. 2). The active fractions were collected, concentrated by ultrafiltration, dialyzed against distilled water and lyophilized. The lyophilized cholesterol esterase showed a single band on polyacrylamide disc gel electrophoresis and SDS-polyacrylamide gel electrophoresis. In SDS-polyacrylamide gel electrophoresis, the molecular weight of the enzyme was estimated to be about 12000 (Fig. 3). In the present and previous experiments, ${ }^{1 \prime}$ the specific activities of the most highly purified enzymes were 36.3 and $9.9 \mathrm{U} / \mathrm{mg}$, respectively. The present purification procedures were thus considered to be more effective than the previous ones.

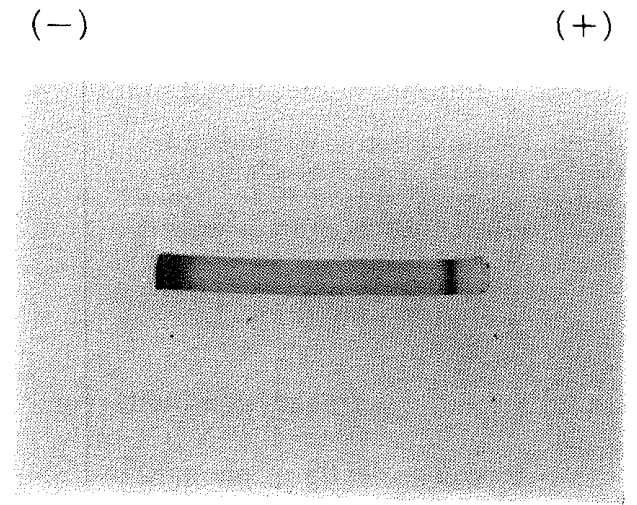

a)

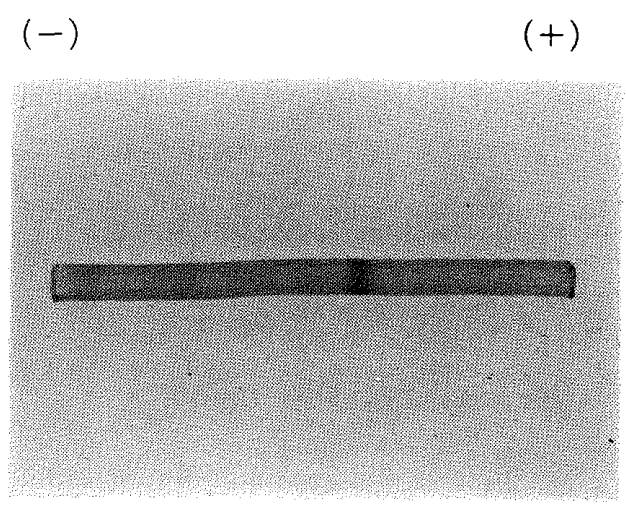

b)

Fig. 3. Electrophoretic Patterns of Purified Cholesterol Esterase

a) Polyacrylamide disc gel electrophoresis.

b) SDS-polyacrylamide gel electrophoresis.

TABLE I. Properties of Lipolytic Enzymes

\begin{tabular}{|c|c|c|c|c|}
\hline & \multicolumn{2}{|c|}{ Affinity } & \multicolumn{2}{|c|}{ Activity } \\
\hline & Cholesterol & $\begin{array}{l}\text { Palmitoyl } \\
\text { cellulose }\end{array}$ & $\begin{array}{l}\text { Cholesterol } \\
\text { esterase }\end{array}$ & Lipase \\
\hline $\begin{array}{l}\text { Cholesterol esterase } \\
\text { (Streptomyces lavendulae) }\end{array}$ & - & + & + & + \\
\hline $\begin{array}{l}\text { Microbial cholesterol esterase } \\
\text { (Boehringer mannheim GmbH) }\end{array}$ & + & + & + & + \\
\hline $\begin{array}{l}\text { Cholesterol esterase } \\
\text { (Bovine pancreas) }\end{array}$ & + & + & + & + \\
\hline $\begin{array}{l}\text { Lipase } \\
\quad(\text { Geotrichum candidum })\end{array}$ & - & - & - & + \\
\hline $\begin{array}{l}\text { Lipase } \\
\text { (Porcine pancreas) }\end{array}$ & + & + & - & + \\
\hline
\end{tabular}

Affinity was investigated as follows; the enzyme was applied to a micro column $(0.46 \times 6 \mathrm{~cm}$; , and after washing with $10 \mathrm{ml}$ of buffer the adsorbed enzyme was eluted with $1 \%$ Triton X-100. 
The adsorption of cholesterol esterase on an affinity adsorbent has not previously been reported. The affinities of this and the other enzymes for cholesterol and palmitoyl cellulose were different depending upon the enzyme source. As shown in Table I, microbial cholesterol esterase (Boehringer Mannheim $\mathrm{GmbH}$ ) and pancreatic cholesterol esterase were adsorbed on cholesterol and palmitoyl cellulose, but cholesterol esterase from Streptomyces lavendulae was only adsorbed on palmitoyl cellulose. Pancreatic lipase was adsorbed on cholesterol and palmitoyl cellulose, but lipase from Geotrichum candium was not adsorbed on either adsorbent. The adsorption of proteins due to interaction between a hydrophobic adsorbent and a site other than the catalytic site is termed hydrophobic affinity adsorption, ${ }^{11)}$ and is presumably the mode of adsorption in these cases. All the tested cholesterol esterases could hydrolyze cholesterol esters and triglyceride. However, two of the lipases could not hydrolyze cholesterol esters. Cholesterol esterase from Streptomyces lavendulae appeared to be different from other cholesterol esterases as regards its affinity for cholesterol. These affinity properties of lipolytic enzymes for cholesterol and palmitoyl cellulose may be useful in classifying the enzymes.

11) H.L. Brockman, J.H. Law, and F.J. Kezdy, J. Biol. Chem., 248, 4965 (1973); M.W. Davey, E. Sulkowski, and W.A. Carter;.j. Biol. Chem., 251, 7620 (1976); M. Sugiura and M. Isobe, Chem.*Phavm. Bull. (Tokyo), 24,72 (1976). 